$1200.1]$

\title{
On Not Defending Poetry: Spenser, Suffering, and the Energy of Affect
}

\author{
JOSEPH CAMPANA
}

JOSEPH CAMPANA is visiting assistant professor of English at Kenyon College, where he teaches Renaissance literature, women's and gender studies, and creative writing. He is completing a project on the 1590 Faerie Queene entitled "Suffering Romance: Edmund Spenser and the Matter of Poetry." Graywolf Press will publish his collection of poems, The Book of Faces, in 2005.
T HE HISTORY OF POETRY IS A HISTORY OF APOLOGY. EARLY MODern English writers, faced with a brave new world of anxieties about the value, validity, and cultural uses of poetry, produced myriad literary apologies. Philip Sidney and Thomas Lodge defended poetry, while Thomas Heywood, Phillip Massinger, and George Whetstone defended drama. In his translation of Ludovico Ariosto, John Harington not only defended poetry but also appended to Orlando Furioso (1591) a moral allegory. Rhyme, imitation, and classical meter were attacked and heartily defended, as were religious poetry, difficult poetry, and tragicomedy. ${ }^{1}$ Sidney easily defends poetry against the claim that it is less true and less useful than sciences such as geometry and astronomy and professions such as law and medicine (23). But he sees a greater challenge to poetry (one requiring a stronger defense) in the claims for the superiority of philosophy and history, which he appropriates in his defense of poetry. Poetry provides a "perfect" or "speaking picture," a clear rhetorical image that illustrates the moral lessons of philosophy and history (32-33). The simultaneous publication of Sidney's work as A Defence of Poesy and An Apology for Poetry (1595) may have been an accident of history, but the slippage between apology and defense is no mere accident of usage. To defend poetry, for Sidney, is to define it as capable, by virtue of a moral force, of beating back a crowd of imposing rival claimants, each asserting a privileged access to truth and a greater capacity to represent reality. Out of this heroic ethos emerges the real work of poetry: the creation of clear rhetorical images of moral truth. ${ }^{2}$ Sidney divorces poetry from the energies in language that such clear rhetorical images never capture. ${ }^{3}$ Such iconic, moral clarity appears ideal only when language is divorced from what makes it resonate so powerfully with bodily

(C) 2005 BY THE MODERN LANGUAGE ASSOCIATION OF AMERICA 
experience: its recalcitrant physicality, its vulnerability to time and change, and its capacity to excite and transmit affect. ${ }^{4}$

By not defending poetry, Edmund Spenser exposes the consequences of Sidney's heroic rhetoric of defense. In a literary tradition full of apologies, confessions, and retractions, Spenser seems never to have written one. ${ }^{5}$ To be sure, a number of texts might appear to reflect the apologetic tone of the day: The Shepheardes Calendar (1579) - especially the October eclogue-with its ambiguous commentary by E. K., the "Letter of the Authors," and the proems to books 2, 3, and 4 of The Faerie Queene $(1590,1596)$. Yet these various metapoetic commentaries question the cultural status of the poet or discuss aspects of poetic representation; they neither defend nor excuse the practice of poetry. Spenser does respond to criticism of his own poetry at the opening of the Legend of Friendship, which begins the 1596 continuation of The Faerie Queene. But instead of describing or defining poetry, he defends and describes the nature of love, the misapprehension of which, he claims, has provoked his opponent's unjust remarks.

Why does Spenser deflect a defense of poetry into a defense of love? Eros was one way of disarming aggressive masculinity, as the proem to the first book of The Faerie Queene makes clear; the poet invokes Cupid and Venus to help him cool the rage of Mars. The heroic Sidney defends poetry at the price of restricting it to a narrow band of moral effects associated with the clarity of visual form. Spenser foregrounds what is most vital and moving about poetry by turning away from forceful visuality and locating an energy in intense experiences of physical and affective pain. This demilitarization of poetic practice releases a communicable energy rooted in the experience of human corporeality, an energy that resonates with the body and between bodies, giving poetry both its feeling of reality and its capacity to move.
Poetry has been a problem at least since Plato precisely because its reality was as questionable as the morality of its depictions; its practice was subject to charges of irrationality, irrelevancy, and immorality. Criticism was born from the act of apology provoked by such responses. "As a consequence," M. H. Abrams argued nearly half a century ago, "literary criticism has been maneuvered into a defensive stance from which it has never entirely recovered" (2). Margaret W. Ferguson, in her subsequent study of early modern defenses of poetry, takes issue with Abrams's position, yoking his desire to free literary criticism from the burden of self-explanation to an "ideal of existence in a realm where one can avoid explaining oneself to foreigners-those who may not understand, much less approve of, one's words or deeds." Her claim rests on the conviction that "only those who possess absolute power, or absolute confidence in their power and their right to it," can exempt themselves from the discourses of defense, apology, and excuse (2). If the danger of Abrams's position is that it tends toward an insular view of poetry, the danger of Ferguson's position is that it assumes an innate difficulty and indirection that make poetry the property of the more ethically aware literary critic. Despite this difference and others, both Abrams and Ferguson assent to the proposition that poetry is a problematic discourse while they also constitute its ambivalent status as a problem for critics.

What about poets or other readers? Abrams may, in his essay, link the apologetics of poetry to "the perennial concern about the clash between what poets say and what their readers believe to be true" (1). Yet he remains concerned for the status of literary critics and their criticism, as does Ferguson, although the authors she considers (including Sidney and Tasso) were poets and critics alike, as were so many practitioners of New Criticism. Abandoning the language of violence im- 
plicit in the language of defense need not lead to the isolation of poetry, poets, and literary critics from wider arenas of public concern; indeed, it may facilitate their participation in those arenas. Abrams's desire that poetry be considered "poetry and not another thing" responds to a history of rivalry stretching from Sidney's defense to New Criticism, in which poetry must vie with philosophy, history, morality, or science to claim privileged access to "truth" (2-3). Robert Matz reminds us that recent "skepticism about the literary could cut more than one way, that its effects are not necessarily only politically progressive, and that whatever value is still accorded the signifiers 'Renaissance' or 'literature' might need to be capitalized on as well as demystified" (128).

Of the more recent attempts to grapple with the problem of poetry's place in the world, Dana Gioia's “Can Poetry Matter?”published first in the Atlantic Monthly (1991) and later in an eponymous collection of essays-contains some of the defensive tone that Abrams deplores and Ferguson requires. Gioia's effort to steer a course for poetry in a time of apparent isolation from the general public provoked controversy. The release of the second edition of his collection on its tenth anniversary coincides with his appointment as the first poet to chair the National Endowment for the Arts. For Gioia, poetry can matter if it combats the specialization and segmentation of literary audiences. It is critical, then, to maintain poetry's civic function, which lies in "improving the health of the language" of a nation by keeping it "clear and honest" (18). Citizens must not lose the "power of language" lest they become "slaves" to those who possess it (17).

The language of defense in Abrams, Ferguson, and Gioia typifies the way the efficacy of poetry has been traditionally tied to a concatenation of power and clarity. As in Sidney's Defence, this notion of poetry's power already disposes us to an understanding of literature determined by a language of force linked to the privileging of iconic visuality as a signifier of rational clarity and moral self-possession. This contemporary understanding of poetic language taps into a historical ambivalence in both rhetoric and poetics about the relation between visuality and vitality. The often-cited Horatian dictum ut pictura poesis says that poetry derives its power from a crystalline visuality (see Hagstrum; Steiner). In his Ars Poetica, Horace claims that "less vividly is the mind stirred by what finds entrance through the ears than by what is brought before the trusty eyes, and what the spectator can see for himself" (lines 180-82). Precisely this understanding of poetry's ideal visual clarity governs John Hughes's description of poetic invention in the introduction to his 1715 edition of The Faerie Queene. ${ }^{6}$ Hughes refers to the "principal part of poetry" as the "power of raising images or resemblances of things, giving them life and action and presenting them as it were before the eyes," and says that this power has "something in it like creation" (80). Hughes participates in the Horatian tradition that conflates "the power of raising images" and the attempt to convey "life and action," which in the rhetorical tradition are denoted by the frequently conflated terms enargeia and energeia. ${ }^{7}$

The triumph of Sidney's defensive poetics, with its taste for moral and visual clarity, has so colored the language of criticism as to distract us from Spenser's interest in poetry's capacity to communicate the painful vitality of lived experience. Ironically, the overflowing energy of poetry is most powerfully felt in The Faerie Queene where the poem dwells on temperance, the virtue of moderation. This interest in energy, its lack and excess, appears particularly as a problem of masculinity, for if The Faerie Queene is a moral work, it is one to the extent that virtue, as masculinity, is of primary concern. Spenser's unique insights prove vital in a time when the dehiscence of 
recent approaches to early modern literature and culture makes particularly tense the rivalries that have come to define the truth of literature and its relation to other cultural forms. The Faerie Queene suggests that what is most real about lived experience-pain, affect, and carnality_can be best conveyed by poetic language when that language is not confused with or subjected to the language of science, history, or philosophy. I do not suggest that early modern poetry or today's criticism should have no traffic with science, history, or philosophy. Rather, I challenge the assumption that we must defend poetry by locating its value in the clarity of greater external truths, as if to save poetry from irrelevance in acts of critical rescue.

As Spenser shows us repeatedly in The Faerie Queene, acts of rescue are themselves complex expressions of force that affirm an ultimately destructive heroic ethos. The danger of rescuing or defending poetry, he knows, is that violence might become naturalized as a species of clarity or truth. Spenser abandons the ideal of violent clarity common both to the literary defense and to Sidney's heroic aesthetic. The rhetorical tradition provides the terms enargeia and energeia to name a distinction between visuality and vitality, between clarity and energy. A chain of association stretching from Aristotle and Quintilian to George Puttenham and Sidney reveals how an emphasis on visuality, enargeia, renders poetry a system of representation that restrains the energy of physical and affective experience in order to establish a moral clarity rooted in appeals to èthos, or reasonable and moderate emotion. Energeia appeals to pathos, or intense and painful affect, and would become the basis of Spenser's poetics.

The Faerie Queene explores how language communicates the phenomenological reality of corporeal experience, which emerges most dynamically in the energy passing between bodies in moments of intense suffering and sympathy. Attending to the energy of affect in experiences of suffering and sympathy in The Faerie Queene offers new ways of approaching Spenser's poetry, just as Spenser's poetry offers new ways of thinking about poetry's capacity to resonate with what is most material and real about experiencing ourselves as bodies living in dense social networks of affect and obligation.

The conflation of energeia and enargeia characteristic of Sidney's Horatian poetics occludes the immediacy, the physicality, of affective and bodily experience because it defines visuality as the source of a lifelike clarity that guarantees the persuasive power of language. Neither Sidney nor Horace was the first to locate in the image the source of poetry's persuasive appeal. Aristotle's Rhetoric describes the usefulness of metaphors, or "smart sayings" notable for proportion and wit as well as for a quality he names energeia, which refers to activity, action, performance, force, and vigor. Yet as Aristotle introduces the term energeia, frequently translated as "actuality," he evokes a similar notion, enargeia, which refers to clarity, distinctness, vividness, and self-evidence:

We have said that smart sayings ... set things before the eyes. We must now explain the meaning of "before the eyes" and what must be done to produce this. I mean that things are set before the eyes by words that signify actuality [energeia].

$(3.11 .1-2)$

What possesses actuality, or energeia, sets things "before the eyes." In defining energeia in language (what we might call vitality), Aristotle conjures vivid, visual appearance, though he never uses the term enargeia. Thus, the efficacy of language depends solely on visual appearance. ${ }^{8}$ Aristotle's conflation of the concepts informing the terms energeia and enargeia conditions the history of rhetoric, as reflected by later writings. The difference in spelling between enargeia and energeia is 
slight, and it in part explains the confusion of commentators from Aristotle to the present. The conceptual difference, however, between vitality and visuality is critical. At stake in the confusion of visuality and vitality is not merely the value of poetry but also the way we imagine language to affect an audience-either as the forceful imposition of clarity or as the evocation of a sympathetic resonance.

Like Aristotle, Longinus and Quintilian emphasize the visual qualities of language, but they also locate a fundamental sympathy at the center of effective rhetoric. In $\mathrm{On}$ the Sublime, Longinus describes energeia as an immediacy or urgency in language that "introduce[s] events in past time as happening in the present moment" and "makes the audience feel themselves set in the thick of danger" (25-26). Energeia turns a narrative of distant events into the experience of present immediacy. According to Quintilian, " $[\mathrm{t}]$ he heart of the matter as regards arousing emotions, so far as I can see, lies in being moved by them oneself." " While both Longinus and Quintilian stress the value of sympathetic participation, Quintilian requires that this emotional state be evoked solely by visual means, for by bringing a scene before the eyes, one can not only harness powerful emotion but also put to good use the "mental vice[s]" of idle daydreaming and wishful thinking. Only by harnessing powerful affect and presenting clear images does one assuage anxieties about the capacity of language for idle daydreaming and wishful thinking. Yet Quintilian also admits, "[E]motions after all are not in our power" (6.2.29-30). Successful speakers must be moved in order to move, but they must harness the potentially overwhelming energy of affect, bending it to their will. The iconic visuality of rhetorical clarity enables the conversion of unbounded vitality to effective spectacle, of energeia to enargeia.

The visuality prized by Aristotle, Horace, Quintilian, and Longinus provides the means by which the vitality of affect is harnessed, and this visual clarity is more compatible with reasonable, moderate $\bar{e}$ thos than with the disturbing energies of pathos. This conversion of energy to force and of vitality to visuality is characteristic of ways of thinking about poetry in early modernity, ways from which Spenser deviates. Though Puttenham's The Arte of English Poesie (1589) distinguishes between two varieties of "ornament"-enargeia ("outward shew") and energeia (what is "inwardly working a stirre to the mind" [155]) - both terms are overdetermined by the framing visual concept of ornament and by the notion of force, what Puttenham calls "strong and vertuous operation" (61).

Masculine power, the "forcibleness of the writer," would define energeia for Sidney too and would be linked necessarily in his Defence to an understanding of poetry as essentially visual: a "speaking picture-with this end, to teach and delight" (19). "Heart-ravishing knowledge" comes of poetry, which is the "first light giver to ignorance" and allows one to overcome the limitations of nature and escape the morally degenerating "clayey lodgings" of the human body. Sidney celebrates the way truth may be "figured forth by the speaking picture of poesy," noting in particular the way in which good writing produces iconic figures: "wisdom and temperance in Ulysses and Diomedes, valour in Achilles ... and, to fall lower, the Terentian Gnatho and our Chaucer's Pandar so expressed that we now use their names to signify their trades" (33). He imagines poetry as a force that produces vivid figurations, near personifications, which solidify mobile affects and desires into character types designed to instruct readers in moral virtue. Poetry, in Sidney's paradigm, evokes the persuasions of Quintilian's èthos, which are "recommended primarily by goodness: not only mild and calm, but usually attractive and polite, and pleasing and delightful to listeners" (Quintilian 6.2.13). 
Spenser struggled to develop a poetic style that would resonate with affective and bodily experience and tap the energies of $p a$ thos. He could do this only by circumventing anxieties about the legitimacy of poetry that restricted the range of poetry to defensive rhetoric, moderated affect, visual clarity, or moral rectitude.

One of the more recent manifestations of anxiety about the function of poetry coincides with the critical return to the distinction between enargeia and energeia in the influential work of Stephen Greenblatt. Greenblatt associates enargeia with rhetoric, with which "only a reality-effect is conjured and nothing more" (“Touch" 29). Energeia gives birth to the term energy, which Greenblatt describes in his influential Shakespearean Negotiations, subtitled The Circulation of Social Energy (2-20). In this scheme, the social provides the animating energy for a literary work otherwise composed of mere surface reality effects. ${ }^{10}$ Though Catherine Gallagher and Greenblatt's Practicing New Historicism reserves a good deal of "piety" for the literary (9), the literary is only ever that through which the "sweet familiar light of the everyday" shines. ${ }^{11}$ Even the modernist poets to which Practicing New Historicism has recourse conflate vitality and visuality: Ezra Pound's "Luminous detail" and William Carlos Williams's interest in "the strange phosphorus of the life" seem to find energeia only in enargeia (15).

Attuned to the seductions of luminous clarity, Spenser turned his attention from enargeia, which is aligned with the moral clarity of ethos, to energeia, which is aligned with the affective resonance of pathos. For him, the value of poetry derives neither from its moral and mimetic properties nor from its ability to reflect or refer to social experience but, rather, from its capacity to convey the vitality of bodies endowed with pain, affect, a vulnerability to change, and a capacity for motion. This concern for the economy, or flow, of energy that lends materiality its feeling of reality Spenser called temperance.

While Spenser opens the Legend of Temperance (book 2 of The Faerie Queene) with what appears to be a defense of poetry, he veers away from the pleasing poetic surfaces that lead to moral education and that Sidney justifies in his Defence. Spenser's proem stakes a larger claim for the material reality of the poetic imagination. Faced with those who deem his "antique history" little more than "th'aboundance of an idle braine" or a "painted forgery" (2.proem.1), Spenser shifts from a strategy of defense to one of redefinition. The problem of the believability of this poetic endeavor rests in its failure to appear as a visual object of knowledge. Thus, he may "vaunt" the "happy land of Faery ... yet no where [does it] show"; he may "vouch antiquities," but "no body can know" them. The veracity of Faeryland is fallaciously tied to visual verification, according to this proem: "Why then should witlesse man so much misweene / That nothing is, but that which he hath seene?" (2.proem.3.4-5). The much noted examples of "great Regions" that, like Spenser's Faeryland, the reader will also have never seen in person are "Indian Peru" and "fruitfullest Virginia" along with the "Amazons huge riuer," which the reader will not have "in ventrous vessell measured." These exotic locales appear as objects of novelty and discovery but refuse to come fully into view despite being subject to conquest. They are, rather, likened to other such worlds, whether on the moon or elsewhere:

What if in euery other starre vnseene Of other worldes he happily should heare?

He wonder would much more: yet such to some appeare.

Of Faerie lond yet if he more inquire, By certaine signes here set in sundry place Hey may it find; ne let him then admire, 
But yield his sence to be too blunt and bace. That n'ote without an hound fine footing trace.

(2.proem.3-4)

"Faerie lond" defies precise location and measure; to approach it, one must seek with different senses. Spenser here asks his reader to abandon the desire for visually objectified knowledge-the real as what is seen and empirically verified. Whereas visuality is tied to the violent discovery of the New World, hearing and scent offer an approach to the imaginative landscape of Faeryland, which is palpable in the rhymes that close the third and fifth stanzas ("heare," "appeare," and "eare").

Even as Spenser compliments Elizabeth, describing his Faeryland as the "faire mirrhour" in which she might see the "antique Image" of her "auncestry" (2.proem.4.7, 9), he swerves away from the paralyzing visuality of her appearance. His task is to "enfold / in covert veil, and wrap in shadow's light" the violent brilliance of Gloriana, by which one might be "dazled" (2.proem.5.1-2, 5). This gesture might well seem to be little more than the parlaying of a defense of allegory into a compliment to the queen. On the contrary, I suggest that the shift away from violent visuality toward the slender substances of covert veils and shadow's light ("clowdily enwrapped" is one description of allegory in the "Letter of the Authors" [1: 167-70; 168]) signals an interest not only in the subtle materiality of poetic language but also in poetry of a different sense. In The Faerie Queene, antique images are always in danger of resolving into painted forgeries or idle portraits, which is a concern, as critics have pointed out, for Protestant iconoclasts (see Gross; Kane). More important, however, is that objectified, reified images lack the vitality of what Spenser describes earlier as poetry's ideal: the "matter of just memory" (2.proem.1.5). Memory, here, is not a frozen portrait of the past, like the monuments and images that will be referred to frequently in the Legend of Temperance.
It is something much more like Augustine's memoria, which refers equally to the cognitive activity of consciousness and to the mobility and physicality of memories that swarm about, forcing themselves into consciousness (10.8.12). Spenser's antiquity contains Henri Bergson's élan vital, which is simultaneously "the continual elaboration of the absolutely new" and "a persistence of the past in the present" $(14,23)$. Faced with the age of the new science and the New World (both emblematized by discovery-the violent visuality of knowledge, cognition, and exploration), Spenser seeks a different futurity in an occluded mythic past, one neither historical nor empirical, known as antiquity. This past is what he refers to as Faeryland. He locates there a vitality that poetry, working with different senses, can convey when it is free of the organizing violence of moral clarity.

Yet the seemingly even-tempered poetics of èthos recommended by Quintilian's rhetoric and Sidney's Defence has governed almost exclusively the reception of the second book of Spenser's Faerie Queene, which is also the section of The Faerie Queene most explicitly concerned with the problem of aesthetic experience. The Legend of Temperance seems to present itself as a work in which moderation and moral rectitude govern our understanding of the role of poetry. Here we apparently find Milton's “sage and serious" Spenser (158), whose patron of temperance, Guyon, experiences the moral dangers of this world in two primary manifestations: the cave of Mammon and the garden of Acrasia. Critics, tending to take Milton's directive, have been captivated by the state of Guyon's soul in his temptation by Mammon, by the care and detail in Spenser's allegory of the temperate body at the House of Alma, and by the temperate treaty making between Medina and her extreme sisters, Elissa and Perissa. Mostly, critics have been preoccupied with the Bower of Bliss-perhaps the most famous 
episode in The Faerie Queene and, as Greenblatt puts it, "one of the great cruxes of English Renaissance literature" (Self-Fashioning 170). But to the extent that the Bower of Bliss narrows our understanding of the aesthetic to the pleasure of fashioning or appreciating images, it reflects, too, the limitations of presentday discussions of aesthetic work, which fail sufficiently to displace beauty, pleasure, and truth as the central components of aesthetic experience. The spectacular violence and visuality of the Bower of Bliss, its position as a great crux of Renaissance literature, distract us from darker and more powerful poetic possibilities, which are like the "covert veils" to which Spenser turns as, in the proem to the Legend of Temperance, he turns away from the blinding brilliance of Elizabeth.

When we move beyond images of moral rectitude or immoral excess and attend to expressions of a quantitative language of energy and enervation, we discover that the true concern of this book is not with rectitude or with abstinence but with economy, or the regulation of energy. The concerns of monetary economy are certainly present in the Legend of Temperance, not least of all in the distribution of property in Guyon's encounter with Medina or in the temptations of the cave of Mammon. But the primary operations of economy in the book occur at the level of the body, where the distribution of pain, energy, and affect are of central concern.

As Max Weber has remarked, the early modern period shows a surprising "combination of religious control of life and an extremely well developed business sense" (7). The call to work that Weber identifies as central to Protestant theology and practice, with its "negative attitude ... toward all sensual and emotional elements in culture and subjective religiosity" and its "fundamental rejection of every kind of culture of the senses" (74), indicates that the work of primitive accumulation, the activity that for
Marx characterized the transitional period after feudalism when massive social and political changes prepared the way for modern capitalism (667-70), also occurs at the level of the flesh. If èthos is to be maintained, bodily affect and energy must be available for practical use, and pain must be made to signify and converted to usable labor. That is, pain and affect remain a problem for the notion of economy. Weber notes that

emotion can experience such a heightening that religious feeling can take on a truly hysterical character and then achieve precisely the opposite effect of that sober and austere discipline into which the systematic "holy life" of the Puritan takes a man, namely a weakening of those "inhibitions" which support the rational personality of the Calvinist against "emotional states." This emotional heightening occurs through the alternation ... between semi-sensuous states of religious exaltation and periods of nervous exhaustion, when God seems "remote."

The problem of painful affect is the problem of vitality, most notable in states of excess energy and extreme enervation, both of which disturb the stable economies that allow the Protestant subject to serve the spirit of capitalism. The Legend of Temperance stages the failure of this poetics of èthos, which, in accordance with Sidney's dictates, would work in the service of this economic agenda. We see the flesh anatomized and scoured of the taint of carnality in the House of Alma. We see pleasure annihilated in the Bower of Bliss. We see Guyon chain and bind the personifications Occasion and Furor, which are, respectively, the trigger of intense affect and its extreme manifestation. In each case, allegorical representations, founded on the principle of enargeia, visually and violently objectify affective and bodily experience. ${ }^{12}$ Yet specters of perverse sensation, Meleager and his army, assault the House of Alma and nearly overrun the castle. The destruction of the Bower 
of Bliss is extreme in its intemperance and presents a famously dissatisfying conclusion to the Legend of Temperance. The binding of Furor and Occasion presents a desperate doubling: they are first objectified as personifications and then bound in chains by Guyon, who later learns the futility of attempting to contain them. Like alternating currents, pairs of male characters-Mordant and Verdant (whose names mean "death-giving" and "lifegiving") and Pyrochles and Cymochles (who represent fiery irascibility and watery uxoriousness) - suggest an exchange of energy, as does the culminating scene of the Bower of Bliss, which finds Acrasia hovering over Verdant, sucking "sprite," or energy, from his eyes (2.12.73.7). Spenser's concern for energy as it materializes in a poetics of painful affect is especially evident in two episodes: Guyon's encounter with the dying Amavia and the sojourn in the cave of Mammon, which causes Guyon's subsequent collapse.

In the explanatory "Letter of the Authors," Guyon's call to work is clear. The Palmer appears at Gloriana's court with the babe Ruddymane ("red or bloody hand"), seeking a knight to defeat the foul enchantress Acrasia, who is responsible for the deaths of the child's parents. In the actual Legend of Temperance, however, Guyon's calling is less clear. First Guyon is distracted by a spectacle of false suffering engineered by the recently escaped Archimago and Duessa. The former narrates a tale of woe and rape that the latter acts out in spectacular fashion, complete with sobbing and "garments rent" (2.1.13.6). Guyon's zeal for righteous combat nearly ends with a battle with Redcrosse, the knight of Holiness, in a well-known and nearly disastrous passing of the torch from one titular knight to the next. But Guyon's encounter with real and unbounded suffering (as opposed to a prepackaged narrative or a striking image) comes as the surprise of a voice echoing in the wood. In two stanzas of complaint, we learn, with Guyon and the Palmer, who merely wait and listen, of the woe of Amavia, who has lost her husband, Mordant, to the wiles of Acrasia, who seduced and then poisoned him. Amavia is left with a corpse, a child, and unmanageable grief. Following this complaint, Spenser offers a startling aural portrait of her suicide:

With that a deadly shrieke she forth did throw,

That through the wood reechoed againe,

And after gaue a grone so deepe and low,

That seemd her tender hart was rent in twaine

Or thrild with point of thoroughpiercing paine;

As gentle Hynd, whose sides with cruell steele

Through launched, forth her bleeding life does raine,

Whiles the sad pang approching she doth feele,

Brayes out her latest breath, and vp her eyes doth seele.

The details of the passage derive from what is heard, not from what is seen. The sealing of the eyes that here signifies death also signifies the shift to senses other than the visual, a shift that the proem foregrounds. Once again, the figure of the trail to be followed by scent appears; in the proem, readers must abandon their sight and rely on the sensitive nose of the hound to find their way to Faeryland. Just previously in this canto, however, Archimago promises to show Guyon the way to the purported rapist Redcrosse, "as sure, as hound / The stricken Deare doth chalenge by the bleeding wound" (2.1.12.8-9). Just a few cantos later, Belphoebe encounters the foolish pair Trompart and Braggadocchio as she pursues her wounded quarry, "a bleeding Hind, / Whose right haunch earst [her] stedfast arrow strake" (2.3.32.7-8). Archimago and Belphoebe present figures of violent predation, but Belphoebe is the most visually iconic figure in the book 
(her blazon, the longest in The Faerie Queene, takes up eleven stanzas) as well as a figure of militant virginity whose violence is unerringly precise (she strikes the "right haunch").

Opposed to Archimago's lust for violence and deception or Belphoebe's commanding visual appearance (a force as potent as her bow), Amavia's suffering unleashes a cascade of sensory experience that resounds through the Legend of Temperance. Her pain echoes throughout the episode despite the efforts of Guyon and the Palmer to contain the flood of affect that pours forth like gore from her wounds. The two men, presenting a stern masculinity, remain most concerned with how the iconic qualities of the scene can be used to construct vivid moral portraits. Indeed, though sound draws Guyon down from his horse, "rush[ing] into the thicke," he only seems to see the scene before him, noting not even a woman or person but a "sad pourtraict of death and dolor." While the blood of her wound ("[f] rom which forth gusht a streame of gorebloud thick") suggests the liquidity and tactility of affect, the visual returns repeatedly to contain the overwhelming grief of the scene $(2.1 .39 .2-4,7)$. This containment is particularly evident in the stanza that depicts the babe Ruddymane, who rests in the dying Amavia's lap, innocently sporting in blood as his mother exsanguinates. The stanza begins with the phrase "Pittifull spectacle of deadly smart" and closes with "Pittifull spectacle, as euer eye did view" $(2.1 .40 .1,9)$. It is as if, faced with the babe's grim and bloody game, the stanza constructs a charm to ward off its horror. The gush of affect is organized into a spectacle that is thus more bearable, even though it is also the most "[p]ittifull spectacle, as euer eye did view." The assertion of the spectatorial "eye" is also the assertion of the subjective I, as the aural pun suggests. Guyon attempts to organize himself psychically as he attempts to contain, visually, Amavia's overwhelming experience.
As the narrative struggles to convert Amavia's energeia into a sentimental spectacle of enargeia, Guyon holds a firm eye (and I) before the scene and remains oddly unmoved by this wounded woman. He responds more to the visual scene of the dead Mordant, in a moment of perilous identification. This "dead corse of an armed knight" (2.1.41.2) displays a smiling, cheerful vitality. Mordant is described in the same stanza as possessing "ruddy lips," "rosy red" cheeks, "the freshest flower of lustihead," and the very "blossom of his age." Guyon seizes up, faced with a figure of masculinity that alternates uncannily between life and death, between ruination and vitality, between masculinity and effeminacy. In response, Guyon's "hart gan wexe as starke as, marble stone" and "all his senses seemd bereft attone" $(2.1 .42 .2,4)$. Mordant's alternation between energy and enervation paralyzes Guyon. Indeed, the specter of vulnerability to pain seems more threatening here than the potentially effeminizing nature of pleasure present in Mordant's flowery appearance. Guyon struggles out of his paralysis when "ruth and fraile affection did constraine, / His stout courage to stoupe, and shew his inward paine" (2.1.42.8-9). This concession to vulnerability is, however, also an attempt to externalize and "show" or objectify "inward" pain visually.

Guyon's attempt to objectify and neutralize suffering prompts an odd act of rescue, as he draws the blade from Amavia's heart and encourages Amavia to divest herself of her grief in a narrative that will make sense of her otherwise incomprehensible pain. Amavia, whom he addresses as "the image ... of rueful pity" (2.1.44.4-5), will presumably gain from this act of rescue, for "He oft finds present helpe, who does his griefe impart" (2.1.46.9). Guyon furthermore promises "to compasse [her] reliefe, / Or die with you in sorrow, and partake your griefe" (2.1.48.8-9). Despite this promise of heroic action, what he actually offers her is the cleansing power of narration. 
After he hauls the half-dead women back to life to tell her story, she obliges him with a narrative and a swift death, which leaves plenty of time for the Knight of Temperance and his guide to clean up.

As if the elimination of Amavia and Mordant were not enough to chase the disturbing taint of pathos from the Legend of Temperance, Guyon begins to moralize furiously, addressing the Palmer. "Old Sire," he begins, "Behold the image of mortality / And feeble nature clothed with fleshly tire" (2.1.57.1-3). The moralizing tag aids the visual objectification of what was once a vitally flowing scene. One must avoid "melting" in pleasure or "frying" in pain, that alternating current Freud describes as "mysterious" to the principle of economy (413). According to the Palmer, we must instead champion temperance, with its power to "measure out a mean." After tears, vows of revenge, and the "due rites and dolorous lament," the Palmer and Guyon believe they have " $[t]$ he end of their sad Tragedie vptyde" (2.2.1.2-3). This phrasing ambiguously translates the pain of Mordant and Amavia into a tidy tragedy, a narrative now possessed by Guyon and the Palmer.

The painful matter of Mordant, Amavia, and Ruddymane soon becomes a moral exemplum presented for the pleasure of its clarity. In the following canto, once Guyon has helped make peace among Medina and her sisters and their consorts, Medina requests the "dolefull tale" so "that we may pitty such vnhappy bale, / And learne from pleasures poyson to abstaine" (2.2.45.1, 3-4). Guyon obliges this request for a moral exemplum and in so doing delivers more pleasure than pain:

When of his pitteous tale he end did make Whilest with delight of that he wisely spake, Those guestes, beguiled, did beguile their eyes Of kindly sleepe, that did them ouertake.

Amavia and Mordant are barely in the grave by the time they have become a bedtime story to delight the sleepy guests of Medina's castle. Does this "delight" stem from the narration or from the wise, moral conclusion? From what does this beguilement derive, the enchanting powers of narration or the comfortable shelter of the castle? The closing moment crystallizes a critique of Sidney's temperate poetics of èthos, which delights and instructs, coating a galling moral lesson with the pleasurable veneer of poetry. For not only does this tactic grossly use the suffering of others, it also encourages a sentimental pleasure in compassionating others for their suffering, which is perilously close to a sadistic pleasure in their suffering. As Max Horkheimer and Theodor Adorno argue, "[A]musement has always meant putting things out of mind, forgetting suffering" (116).

The painful affect that pours from the wounded heart of Amavia and stains the tiny hands of Ruddymane appears deep in the subterranean world of Mammon, god not only of wealth but also of the "world and worldlings" (2.7.8.1). Worldly economy is and is not of concern in the cave of Mammon, for while the trappings of that economy are everywhere, wealth and ambition are never real temptations for Guyon, who does little in this episode but disapprove. ${ }^{13}$ Mammon's periodic offers of wealth, power, and the hand of his daughter, Philotime ("love of honor"), are punctuated blandly and sententiously by Guyon's steadfast refusals. Of the many strange experiences of Mammon's underworld, the most important for Guyon present the temptation of intense affect.

In the cave of Mammon, the desire to damn the flow of affective energy appears in a series of personifications. Guyon first encounters ones of dark affect: Pain, Strife, Revenge, Despite, Hate, Sorrow, Shame, and others. If the point of personification is both to embody and to contain mobile affect, one pair is of particular note for remaining mobile and affecting: 
And ouer them sad Horrour with grim hew, Did alwayes sore, beating his yron wings; And after him Owles and Night-rauens flew, The hatefull messengers of heauy things, Of death and dolour telling sad tidings; Whiles sad Celeno, sitting on a clift, A song of bale and bitter sorrow sings, That hart of flint a sunder could haue rift: Which hauing ended, after him she flyeth swift.

Despite the aversiveness of this pair, something strangely touching remains in the suggestion of an erotic narrative, as if they reprise the plot of Mordant and Amavia. Celeno's song opens out of wrenching grief, like Amavia's "rent" heart, to break even the sternest "heart of flint." The two figure the persistent physicality ("heavy things") and mobility ("after him she flyeth swift") of affective energy.

While Celeno and Horror present the circulation of painful, bodily affect, Disdain presents a portrait of Guyon's virulent temper and his apparent invulnerability to affect. Disdain is a "sturdy villain":

But he himselfe was all of golden mould, Yet had both life and sence, and well could weld

That cursed weapon, when his cruell foes he queld.

The impressive figure of Disdain combines invulnerability ("For nothing might abash the villein bold, / Ne mortall steele emperce his miscreated mould" [2.7.42.8-9]), anger, and a need for restraint ("Mammon did his hasty hand withhold" [2.7.42.6]), making him another Guyon. At the opening of the Legend of Temperance, Guyon appears as "A goodly knight, all armd in harnesse meete, / That from his head no place appeared to his feete" (2.1.5.8-9). Even as he resists immoderate affect, his sojourn demonstrates that the temptation of the cave of Mammon is pathos and that Spenser succumbs willingly.
While Guyon, preferring emotional abstinence and militant temperance, may refuse to participate in the active, physical energy of affect, his much noted collapse outside the cave (after three days without food, drink, or rest) conveys negatively, as deprivation and exhaustion, the fundamental physicality of his body, which he studiously ignores. His "vitall powres gan wexe both weake and wan" (2.7.65.2) as his "life" "flit[s] away out of her nest," like a sad Celeno. Spenser demonstrates his interest in the flux and flow of energy, which endows the body with vitality and motion, rather than in the triumphant exercise of force. Indeed, deprivation renders the otherwise violent Guyon a site of compassion, as a glorious angel manifests over his prone body like a pulse of lyric energy:

\section{Beside his head there sate a faire young man, Of wondrous beautie and of freshest yeares, Whose tender bud to blossome new began, And flourish faire aboue his equall peares; His snowy front curled with golden heares, Like Phoebus face adornd with sunny rayes, Diuinely shone, and two sharpe winged sheares, \\ Decked with diuerse plumes, like painted Iayes,}

Were fixed at his backe to cut his ayerie wayes.

In the angel coexist energeia, in his youthful, flowery vigor, and enargeia, in his spectacular appearance as a figure of Apollonian brightness and martial prowess. The violence of enargeia is amply figured in the angel's form as well as in his mission. Like the angel who defends the aged Raimondo in Torquato Tasso's Gerusalemme liberata (7.78-83), Spenser's angel has been sent by God "[a]gainst foule feends to aide vs millitant / They for vs fight, they watch and dewly ward" (2.8.2.5-6). Angels demonstrate a selfless love that occurs here in a defensive posture.

But just as the angel arrives, seeming to embody a heroic èthos, he abandons his 
militancy. Though the angel bristles with armaments, he is also likened to a figure that echoes throughout the 1590 Faerie Queene, an unarmed Cupid:

When hauing laid his cruell bow away, And mortall arrowes, wherewith he doth fill

The world with murdrous spoiles and bloudie pray,

With his faire mother he him dights to play....

In a passage reminiscent of the proem to the Legend of Holiness, which seeks to disarm the violence and cruelty of Mars, the angel shifts from holy warrior to Venus's darling. He vows "euermore [to] succour, and defend" Guyon (2.8.8.5) yet departs immediately after making this promise, leaving the comatose Guyon in the care of the Palmer, who proves useless against the Saracen knights charging to despoil the vulnerable body.

Despite the assigned role of angels in the Legend of Temperance, their function encompasses compassionate witness rather than militant defense. Even as they are introduced at the opening of the eighth canto, their mission is suffused with pathos:

$$
\begin{aligned}
& \text { And is there care in heauen? And is there loue } \\
& \text { In heauenly spirits to these creatures bace, } \\
& \text { That may compassion of their euils moue? } \\
& \text { There is: else much more wretched were the } \\
& \text { cace } \\
& \text { Of men, then beasts. }
\end{aligned}
$$

While God's mercy provides human beings with the protection of angels, angels display a capacity to be moved, through compassion, to manifest materially. We might translate this canto's question, "is there care in heaven?" as, "Do angels have bodies that experience affect?" The answer is emphatically yes. Without compassion, men would be worse than beasts, and it is the beastlike nature of Guyon, reduced to a lump of barely vital flesh, that evokes the care of the angel that hovers over him in sym- pathetic vibration. When Guyon is least active, most prone, he is most human in his vulnerability to the experience of being flesh. He is, briefly, a location of sympathy rather than a personification of moral disdain.

What else might this angelic apparition signify? The questions we ask of his manifestation in this startling scene are those we might ask of poetry. Is the angel the blinding light of a truth that shines through the limited body? Is he the force and truth of poetry? Is the angel, as poetry, useless beauty, transcendent spirit, or cloying sentimentality? Is the angel, like the lyric in Adorno's modernity, a fetish that, at best, exposes the workings of fetishism? Is poetry a violent compulsion or a decadent spectacle? Or is poetry really the prone body of Guyon in need of defense from those who rush to despoil it? Does Arthur's violent magnificence defend or supplant the compassionate pathos of the angel and the vulnerable physicality of the collapsed Guyon?

Like questions about the nature of angels, questions about the nature of poetry are more easily posed than answered. Their difficulty makes our attempt to address them all the more necessary in the shadow of a new millennium, when we ask ourselves, yet again, how poetry matters to and functions in a world of violent action, where clarity and force are valued over complexity and experience. Spenser's angel may function most usefully in being heroically useless to Guyon. Despite his militant trappings, the angel serves no heroic function, as if he could draw poetry away from the language of offense and defense, in which one must choose among equally unsavory roles: the moralistic Palmer, the despoiling infidels, or even the magnificent Arthur, whose virtue in The Faerie Queene is as blinding as it is violent. The angel hovers over Guyon as an embodiment of the sympathy one piece of flesh may feel for another-a sympathy that resonates at the frequency at which poetry also resonates. 
In the landscape of the Legend of Temperance, the angel manifests the vitality and physicality of pathos and thus must be apprehended by those other senses that designate the difference between Spenser's Faeryland and Spenser's England. Spenserian poetics makes available a vitality of material experience otherwise occluded by the clarity and truth that violence comes to be known as. In the midst of the most temperate domain in the Legend of Temperance, the Castle of Alma, Spenser makes this apparent. Before dinner, Guyon and Arthur are given booksa history of Britain for Arthur and a history of Faeryland for Guyon. The former takes up a narrative in which the chaos and brutality of history resolve occasionally into stability: "Braue moniments remaine, which yet that land enuies" (2.10.21.9). Yet the heroic history of England proliferates violence. The narrative Arthur reads asserts consistently and defensively that memory lives on "though carcas sleepe in rest" (2.10.43.9). Faced with the warring instability and "doleful" monuments of Arthur's England, Spenser turns again to Faeryland (and I think here we learn why Guyon is a fairy):

\footnotetext{
But Guyon all this while his booke did read, Ne yet has ended: for it was a great And ample volume, that doth far excead My leasure, so long leaues here to repeat: It told, how first Prometheus did create A man, of many partes from beasts deriued, And then stole fire from heauen to animate His worke, for which he was by Ioue depriued

Of life him selfe, and hart-strings of an Ægle riued.

Spenser's Faeryland is best experienced with senses that do not rely on the violence of moral or rational clarity. Prometheus represents what Adonis will represent in the Legend of Chastity: not clanging, continual war but the experience of a painful and creative vitality providing the spark that turns an endless monument into a living book, leaving behind community rather than corpses. Spenser's poetry asks us to participate in the painful experience of animation and in the vitality that inheres in the opacity of living flesh, which resists the clarity we would bring as we define and defend poetry.

In The Faerie Queene, we are continually invited to feel the physical sympathy, the affective resonance, awakened whenever we make contact with a vitality central to lived experience, a vitality Spenser found most palpable in moments of intense suffering. This vitality cannot be perceived as an object, as something separate from experience; it can be known only when felt materially as the pain of animation that produces sympathetic resonance. The Faerie Queene offers its readers what early modern rhetoric and poetics referred to as energeia, which Spenser conceived of as the energy of experiencing human corporeality in pleasure and in pain: an experience embodied in a physicality uniquely available to poetry. Poetry imagines its way to the real so as not to objectify it. Efforts to define what poetry is and to defend it as useful have, in the tradition of Sidney's Defence, often looked for enargeia, proceeding on the assumption that the "power" of poetry persists in clear perception and expression. But if poetry, as Spenser would have it, runs beneath all clear perception and resonates with the connective tissue of affective and corporeal experience, then all efforts to defend poetry must, fortunately, fail.

\section{NOTES}

\footnotetext{
${ }^{1}$ While difficult poetry was not a recognized category, George Chapman does praise difficulty and obscurity as potentially valuable poetic qualities. In the dedicatory epistle to Ovids Banquet of Sence (1595), Chapman laments, "But that poesy should be as perviall," or easily seen through, "as oratory, and plainness her special
} 
ornament, were the plain way to barbarism" (A2r). See Vickers 392-94.

${ }^{2}$ The exemplary figure of eloquent defense in the exordium of Sidney's treatise is the Italian riding master John Pietro Pugliano, who was of "the noblest of soldiers ... the masters of war and ornaments of peace, speedy goers and strong abiders, triumphers in both camps and courts" (17). As he speaks of poetry, Sidney assumes the language of triumph and the mantle of heroic romance. Robert Matz describes heroic masculinity, the ideal of "warrior service" born of "feudal nostalgia" (21), as central to how Sidney imagined himself as poet, courtier, and critic: "poetry's warrior content must repress what is most basic to the form of that poetry, its existence as a piece of writing, the product of a writer's activity" (73).

${ }^{3}$ As Chapman indicates, it is not visuality that poses a problem for poetry but the desire for iconic clarity: "It serves not a skilful painter's turn to draw the figure of a face only to make it known who it represents, but he must limn, give luster, shadow and heightening; which though ignorants will esteem spiced and too curious, yet such as have the judicial perspective will see it hath motion, spirit and life" (A2r).

${ }^{4}$ Paul Alpers finds a "rhetorical mode" in The Faerie Queene but one that is to be distinguished from Sidney's desire to discover in poetry clear rhetorical images of moral truth. On the contrary, Alpers argues, Spenser's "poetic motive in any given stanza is to elicit a response-to evoke, modify, or complicate feelings and attitudes" (5).

${ }^{5}$ One may wonder about The English Poet, a "lost" work ascribed to Spenser by E. K., who, in the argument of the October eclogue, promises its future publication. See Oruch.

${ }^{6}$ Studies by Bender and by Paglia identify visuality, even violent, iconic visuality (Paglia), as a central virtue of The Faerie Queene.

${ }^{7}$ For the philosophical valences of enargeia and energeia, see Peters.

${ }^{8}$ Martin Jay has argued that not only does the privileging of vision in Greek thought contribute to an "ocularcentrism" increasingly characteristic of Western modernity, it also results in the denigration of other forms of sensory experience and of language itself (33).

${ }^{9}$ Quintilian never uses the term energeia; he does discuss enargeia and phantasiai ("visions ... by which the images of absent things are presented to the mind") in the course of explaining rhetorical appeals not to e thos (temperate, reasonable morality) but to pathos (fierce emotional experience [6.2.26]).

10 "Poetry" is not "the path to a transhistorical truth" but "the key to particular historically embedded social and psychological formations” (Gallagher and Greenblatt 7).

${ }^{11}$ Greenblatt, "Touch” 30. As Matz notes, "contemporary analyses" of early modern poetry often "unconsciously repeat sixteenth-century anxieties about the place of literature, especially in relationship to the 'political'” (3).

${ }^{12}$ See accounts of allegory as the capture of wayward matter by violent form in Teskey and as demonic personification in Fletcher.

${ }^{13}$ On Mammon's gold and the New World, see Read.

\section{Works Cited}

Abrams, M. H. "Belief and the Suspension of Belief." Literature and Belief. Ed. Abrams. New York: Columbia UP, 1958. 1-30.

Adorno, Theodor. "Lyric Poetry and Society." Telos 20 (1974): 56-71.

Alpers, Paul. The Poetry of The Faerie Queene. Columbia: $\mathrm{U}$ of Missouri P, 1982.

Aristotle. The "Art" of Rhetoric. Trans. J. H. Freese. Cambridge: Harvard UP, 1926.

Augustine. Confessions. Trans. Henry Chadwick. Oxford: Oxford UP, 1990.

Bender, John. Spenser and Literary Pictoralism. Princeton: Princeton UP, 1972.

Bergson, Henri. Creative Evolution. Trans. Arthur Mitchell. New York: Random, 1944.

Chapman, George. Ovids Banquet of Sence. London, 1595.

Ferguson, Margaret. Trials of Desire. New Haven: Yale UP, 1983.

Fletcher, Angus. Allegory. Ithaca: Cornell UP, 1964.

Freud, Sigmund. "The Economic Problem of Masochism.” On Metapsychology: The Theory of Psychoanalysis. Penguin Freud Lib. 2. London: Penguin, 1991. 409-26.

Gallagher, Catherine, and Stephen Greenblatt. Practicing New Historicism. Chicago: U of Chicago P, 2000.

Gioia, Dana. "Can Poetry Matter?" Can Poetry Matter? Saint Paul: Graywolf, 2002. 1-21.

Greenblatt, Stephen. Renaissance Self-Fashioning. Chicago: U of Chicago P, 1980.

- Shakespearean Negotiations. Oxford: Clarendon, 1988.

. "The Touch of the Real." Gallagher and Greenblatt 20-48.

Gross, Kenneth. Spenserian Poetics. Ithaca: Cornell UP, 1985.

Hagstrum, Jean H. The Sister Arts. Chicago: U of Chicago P, 1958.

Harington, John, trans. and ed. Orlando Furioso in English. London, 1591.

Horace. Satires, Epistles, [and] Ars Poetica. Trans. H. R. Fairclough. Loeb Classical Lib. Cambridge: Harvard UP, 1926 . 
Horkheimer, Max, and Theodor Adorno. Dialectic of Enlightenment. Trans. Edmund Jephcott. Stanford: Stanford UP, 2002.

Hughes, John. "An Essay on Allegorical Poetry." Penguin Critical Anthologies: Edmund Spenser. Ed. Paul Alpers. London: Penguin, 1969. 78-96.

Jay, Martin. Downcast Eyes. Berkeley: U of California P, 1994.

Kane, Sean. Spenser's Moral Allegory. Toronto: U of Toronto $\mathrm{P}, 1989$.

Longinus. On the Sublime. Trans. W. H. Fyfe. Cambridge: Harvard UP, 1995.

Marx, Karl. Capital. Ed. Frederick Engels. New York: International, 1967.

Matz, Robert. Defending Literature in Early Modern England. Cambridge: Cambridge UP, 2000.

Milton, John. Areopagitica. Prose Writings. London: Dent, 1958. 145-85.

Oruch, James. "Lost Works." The Spenser Encyclopedia. Ed. A. C. Hamilton. Toronto: U of Toronto P, 1990.

Paglia, Camille. Sexual Personae: Art and Decadence from Nefertiti to Emily Dickinson. New York: Vintage, 1991.
Peters, F. E. Greek Philosophical Terms: A Historical Lexicon. New York: New York UP, 1967.

Puttenham, George. The Arte of English Poesie. Introd. Baxter Hathaway. Kent: Kent State UP, 1970.

Quintilian. The Orator's Education: Books 6-8. Trans. Donald Russell. Cambridge: Harvard UP, 2001.

Read, David. Temperate Conquests: Spenser and the Spanish New World. Detroit: Wayne State UP, 2000.

Sidney, Philip. A Defence of Poetry. Ed. J. A. Van Dorsten. Oxford: Oxford UP, 1966.

Spenser, Edmund. The Works of Edmund Spenser: A Variorum Edition. Ed. Edwin Greenlaw et al. 11 vols. Baltimore: Johns Hopkins UP, 1932-57.

Steiner, Wendy. The Colors of Rhetoric. Chicago: $\mathrm{U}$ of Chicago P, 1982.

Tasso, Torquato. Jerusalem Delivered. Trans. Edward Fairfax. Oxford: Clarendon, 1981.

Teskey, Gordon. Allegory and Violence. Ithaca: Cornell UP, 1996.

Vickers, Brian, ed. English Renaissance Literary Criticism. Oxford: Clarendon, 1999.

Weber, Max. The Protestant Ethic and the "Spirit" of Capitalism. New York: Penguin, 2002. 